ticable nature is wholly inoperative,) and the substitution, in lieu thereof, of some more stringent clause in the new Bill, whereby the practising for the sake of gain, in any department of medicine or surgery, by unqualified persons, shall be made a misdemeanour punishable by fine and imprisonment, on conviction before two magistrates.

Signed on behalf of the meeting JAMES KENDRICK, M.D., Chairman.

\section{CHARTER OF THE COLLEGE OF SURGEONS.}

PROTEST, MEMORIAL, AND PETITION, FROM MANCHESTER.

Manchester, March 20, 1845.

Sir,-At a numerously attended meeting of members of the Royal College of Surgeons of England, resident in Manchester and Salford, which was held in the Townhall, on the 18th inst., Dr. Radford, M.R.C.S., \&c., in the chair. 'The annexed protest, memorial, and petition, were unanimously adopted, and they are now in course of signature. It was likewise resolved that a copy of the same should be forwarded for insertion in the Provincial Medical and Surgical Journal.

We are, Sir,

Your obedient serrants,

THOS. DORRINGTON, , Hon. To Dr. Streeten.

To the President, Vice-Presidents, and Council of the Royal College of Surgeons of England.

Gentlemen,-We, the undersigned, Members of the Royal College of Surgeons of England, residing in Manchester and Salford, hereby record our indignant protest against certain recent proceedings of the Council of the college.

We have delayed to the present period any combined expression of sentiment with respect to the conduct of the conncil, in executing the provisions of the late charter, earnestly hoping that, on ascertaining the allbut universal feeling of dissatisfaction prevalent, they would, themselves, hare adopted measures which would have led to a rectification of the grierous wrong which members of the college have sustained.

We beg to remind the Council that, prior to the grant of the new Charter, all menbers possessed identity of isurgical honours, so far as these rested upon any tes. timonials obtained from the college; that their motives in complying with its educational requirements, in submitting to its examination, and in purchasing the diploma, were the recognized fact that, by so doing, they received the highest surgical attestation accessible at the time to the English student. Now, however, by recent arbitrary acts of the Council, membership of the college, once a just pride and bnast, has been made to constitute the badge of inferiority.

We do not hold that, in carrying out the provision of any charter, it would have been advisable, or even practicable, for the fellowship to have been extended at once, and without any reserve, to all the members; but we do maintain that nomination to that distinction sould have been guided by some well.defined and intelligible principle, applicable alike in every case, and that it should have been attainable, from the first, under uniform conditions, by every then existing member of the College, without any renewed examination, or further payment beyond some nominal sum towards defraying expences incidental to the grant and execution of the Charter

We reject with scorn the insulting proposal fot gaining the fellowship by additional purchase, after submitting to another examination as to surgical acquirement; a proceeding to which others have not been subjected, whose nomination to the fellowship was preceded by qualifications differing in no respect from our own. The proposal itself we regard as one which, for every reason, no present member of the College can accept without deep degradation.

Finally, we think it right to avow our fixed and unalterable resolution to persevere in the employment of all legitimate means for effecting restitution of our just professional rank and privileges; whereby alone, we conceive, can "the dignity and welfare of the College" be maintained, accordant with the terms of the oath administered to all on admission to the membership.

We have the honour to be, Gentlemen,

Your obedient humble servants.

To the light Hon. Sir James Graham, Bart., Secretary of State for the Home Department.

Sir,-We, the undersigned, members of the Royal College of Surgeons of England, residing in Manchester and Salford, desire to preface the memorial, which we now present to you, with an expression of our obligation for the patient attention you have given to the interests of the medical profession, anidst your important and multifarious engagements.

Fully sensible of the difficulties of your position with respect to any details affecting medical legislation, wo have hitherto delayed to address you, in the confident anticipation that the council of the college to which we belong would voluntarily hare retrieved the Aagrant error it has committed towards the great majority of the members, and have thereby restored to them the rank and privileges in the college, of which they have been 80 arbitralily deprived. Disappointed in this expectation, we yet hoped to have found in the "Bill for regulating the Profession of Physic and Surgery," recently introduced by you into the House of Commons, an effi. cient remedy provided for the grievnus wrong perpetrated against us by the Council of the college; and more ospecially did we expect this, from observing the liberal spirit which you, Sir, displáyed in your speech on introducing the measure.

As, however, so far as our rights in reference to our college are concerned, there is no difference between your present bill and the one you brought before the House at the close of the last session of parliaments we are compelled, by a strong sense of the duty wo owe to ourselves, and a wish to preserve the interests of the college to which we belong, to give expression to our sentiments with freedom and determination.

And first, Sir, we would remark that her most gracions Majesty the Queen, by your advice, granted a new charter to the Royal College of Surgeons, on a petition which, by a gross misrepresentation, was styled "The Petition of the Royal College of Surgeons of London." We take the liberty of observing, that in 
sucb a petition, it was a daring fiction for any twentrone individuals out of a college consisting of twelve thousand members, to designate themselves "the college," without having ascertained and therein expressed the wishes of those over whose interests they " were bound to watch, aud whose rights they were morally pledged to protect. We would remind you, Sir, that the Council of the College of Surgeons, when acting in opposition to the wishes of thousands of its members, could no more with truth be considered " the college," than could the building in which the Council holds its meetings. If, then, it be shown by a general expression of feeling on the part of the members of the college, as we doubt not will be the case, that the proceedings of the council have not met with the sauction of the majority of those whose interests it is bound to serve, we trust that the fact of her Majesty having granted a charter to the college, on a petition which was called, but was not in reality, "The Petition of the Royal College of Surgeons," will not be any hindrance to your advising her most gracious Majesty to grant a new or supplementary charter, in order to restore us to our former position.

From the reply which you are reported to have made to a question put by ColouelWood, in the Huuse of Commoss, on the 7 th inst., in reference to the restoration of our rights, we can only suppose that important infor. mation has been withheld from you as to our present nnsatisfactory position in the College, on which account we beg to direct your favourable attention to the following statements.

When we received our diplomas from the Royal College of Surgeons in London, we were admitted in every respect to a full participation in all the honours and privileges that it was in the power of the college to confer. We all held exactly the same title, and ranked in the college with the most successful and influ. ential of its members. Since the institution of the fellowship we find ourselves in a new position, separated from those with whom we have hitherto been on an equality, and deprived of many of the advantages we sought in associating ourselves with the college. We can easily understand, that in carrying out the powers of the recent charter, it might not have been practicable for the fellowship to have been extended at once by the Council without any reserve to all its members; but we unhesitatingly assert that nomination to that distinction should have been guided by some weil defined and intelligible principle, applicable alike in every case; and that it should have been attainable from the first under uniform conditions by every then existing member of the College, without any renewed examination or further payment, beyond some nominal sum towards defraying expenses incidental to the grunt and execution of the Churter. As it is, the election to the fellowship has been made to depend, for the most part, on the accidents of situation and patronage, nay in some cases on undoubted favouritism, so that our former peers in the profession have been elevated above us on such grounds that no real honour can attach to the possessiou of the title on their part, whilst just and proper feelings of self-respect have been most deeply wounded on ours. On first consideration, it may appear to you that we have in our own hands a remedy for the evil of whlch we complain. It may be asserted that those members who are anxious to obtain the fel- lowship, have still the opportunity of doing so by sub. mitting to the prescribed examination and making the further prescribed payment. The unreasonableness of such a proposition can be fairly appreciated by those only who are practically acquainted with the nature of medical examinations, and alive to the onerous and engrossing character of our pursuits. Can it be expected that those who are already engaged in active practice can sacrifice their valuable time in preparation for an examination in the elements of surgical science, and neglect their important duties to solicit collegiate titles? Is it not most absurd to suppose that some of the oldest members of our college will submit thernselves to an ordeal as to their capability of practising a profession in which they hare, usefully to the public, and honourably to themselves, spent the best part of their lives? Would it not be most degrading for such gentlemen to seek on equal terms with students, for distinctions to which in justice they are already entitled ?

Moreover, we have no confidence that the alterations of which we have already so much cause to complain, will constitute the ultimatum of our degradation. If it have seemed desirable to the council of the college that the surgeons of all the larger hospitals should receive the fellowship, the day is probably not far distant when the proposed Council of Health may see fit to require that every candidate for such situations shall have previously obtained that distinction. At least a preference will, in all probability, be tacitly ararded to those possessing the supplementary diploma. Thus we may, in the end, be excluded from those very situations for we were chiefly ambitious to render ourselves eligible, when we presented ourselves as candidates for the membership of the college.

These, Sir, have appeared to us sufficient grounds for memorializing you on the present occasion; and, as you have expressed a wish to give satisfaction to the whole of the profession, we beg respectfully, but earnestly, to intreat you to precede any further parliamentary discussion of your present "Bill for regulating the Profession of Physic and Surgery," by advising her Majesty to grant a New or Supplementary Charter to the Royal College of Surgeons of England, a Charter of such a nature as shall restore us to our lost rank, and put us on an equality with those who underwent the same course of study, passed a similar examination, and purchascd the same diploma with ourselves. We respectfully assure you that, in our opinion, no course but this can be acceptable to any member who has a proper feeling of self-respect, and a just regard for the oath which he has talien " to maintain the dignity and welfare of the college."

We have the houour to be, Sir, Your most obedient and humble serrants,

To he Honourable the House of Commons of the United Kingdom of Great Britain and Ireland, in Parliament assembled,

The Petition of the undersigned Members of the Royal College of Surgeons of England, residing in Manchester and Salford,

Humbly Sheweth, -

That the Council of the Royal College of Surgeons of England has arbitrarily, and without any intelligible principle, elevated a small number of our body into a collegiate rank superior to our. own, by exercising 
unfairly, in the opinion of your petitioners, certain powers conferred upon it by a charter granted to the college by her Most Gracions Majesty the Queen, in the year of our Lord 1843.

That your Petitioners have thereby been deprived of the high professional position, to obtain which constituted one of their main objects in pursuing the prescribed course of study, submitting themselves to the curgical examination, and purchasing the diploma of the college.

That your Petitioners observe, with unfeigned alarm, that the "Bill for regulating the profession of Physic and Surgery," recently introduced into your Honourable House by the Right Honourable Sir James Graham, is framed so as to sanction and confirm the unjustifiable course which the Council of the College of Surgeons has pursued towards the members of the college.

That your Petitioners had fally expected, after the great dissatisfaction and indignation expressed by an orerwhelming majority of those who constitute the college, at the manner in which the conncil had exercised its powers, that the Right Honourable Sir James Graham, who has lately introduced into your Honnurable House the "Bill for regulating the professiou of Physic and Surgery," would have preceded such bill by advising her Most Gracious Majesty the Queen to grant a supplementary or amended charter to the college, with the viow of restoring to the members the surgical honours and privileges of which they have been injuriously deprived.

That your petitioners, being disappointed in this reasonable expectation, have made a statement of their grievances to the Right Honourable Sir James Graham, Secretary of State for the Home Department, and pemorialized him to comply with their earnest wishes in this matter, before pressing his " Bill for regulating the profession of Physic and Surgery" upon your Honourable House for adoption; and your petitioners, therefore, humbly entreat your Honourable House not to permit the said Bill to be read a second time, until restitution has been made to your petitioners of their Collegiate rank and privileges.

And your petitioners will ever pray.

ROYAL COLLEGE OF SURGEONS.

\section{PROTEST OF THE PRACTITIONERS OF WEST SOMERSET.}

To the President and Council of the Royal College of Surgeons of England.

We, the undersigned, heing Fellows and Members of the Royal College of Surgeons, residing in the western division of the county of Somerset, although averse to taking any steps that might prejudice the interests of that body, particularly at the present crisis, yet feel it due to ourselves, as individuals, to record our earnest and indignant protest against the recent proceedings of the Council in the matter of the Fellowship.

We protest against this as a departure from rules of the College, intended for the protection of its members, inasmuch as the arbitrary elevation of a few to the distinction of a Fellowship, having no particular claim either on the ground of seniority or merit, cannot but be regarded as a virtual degradation of the many who have received no such distinction.

We consider the invitation to the mass of the profession to undergo examination, and to pay fees, in order to obtain the rank which has thus been conceded to a select few without either, to be an affront to all those members of the College.

Henry Alford, F.R.C.S., Francis Welch, F.R.C.S., Charles Hayes Higgins, F.R.C.S, Charles Henry Cornish, F.R.C.S., Gustavus Gidley, Daniel Pargitter, John Liddon, Charles Hugo, William Marwood Kelly, M.D., George Cordwent, Henry Gully Foy, James Wood J. R. Mosse, Robert Dinham, William Beadon, Francis Henry Woodforde, M.D., Henry Liddon, Francis Foster Taunton ; George Kidgell, William Collard Pyne, Wm. Collard Pyne, Jun., S. F. Bridge, Albert Langley, Alexander Edward Webber, Wellington; H. W. Randolph, J. K. Parkinson, Milverton; William Trevor, Dulverton; A. F. Edwards, J. N. Norman, Henry Cotes, Henry L. Nazer, P. L. Hill, Wiveliscombe ; Robert Smith, Bishop's Lydeard; Abraham King, Richard Axford, James Haviland, Bridgewater; J.Jolliffe, Chard ; G. Richard Bart, Ilminster.

\section{HEREFORDSHIRE MEMORIAL.}

TO THE EDITOR OF THE PROVINCIAL MEDICAL AND Sir,

In accordance with a resolution, carried at a meeting of the Herefordshire Medical Association, I have the honour to request that you will insert in the columns of your able periodical, the accompanying memorial, with its signatures, and the protest, at you earliest convenience.

I remain, $\mathrm{Sir}$,

Your obedient servant,

HENRY GRAVES BULL. Honorary Secretary

To the Herefordshire Medical Association.

Hereford, April 5, 1845.

To the Right Honourable Sir James Graham, Baronet, her Majesty's Secretary of State for the Home Department.

The memorial of the Surgeons of the city and county of Hereford,

Sheweth,-

That your Memorialists, members of the Royal College of Surgeons of England, resident in the city and county of Hereford, in compliance with the oath they have taken, on being admitted members of the College, to maintain its dignity and welfare to the utmost of their power, feel it to be an imperative duty respectfully to call your attention to the injustice displayed in the mode of carrying out the charter recently granted to the royal college.

Your Memorialists cannot but feel that the Council of the Royal College of Surgeons of England has broken faith with the general body of the members, by the principle of election to the newly created grade of the fellowship, which it has seen fit to pursue. Foll power was given to the council by the new charter, to carry out this principle in a way, which would not have interfered with existing rights and privileges; but 